Prosiding Seminar Nasional Teknologi Informasi dan Kedirgantaraan : Transformasi Teknologi untuk Mendukung Ketahanan Nasional, Yogyakarta, 13 Desember 2018

SENATIK 2018, Vol. IV, ISBN 978-602-52742-0-6

DOI: http://dx.doi.org/10.28989/senatik.v4i0.140

\title{
THE ASSESSMENT OF INTERNAL CONTROL SYSTEM IN MANAGEMENT OF INFORMATION TECHNOLOGY BASED ON COSO IC
}

\author{
Muhammad Fadlan'), Wing Wahyu Winarno'), Kholid Haryono ${ }^{3)}$, Muhammad ${ }^{4}$ \\ ${ }^{1,4)}$ Program Studi Sistem Informasi, STMIK PPKIA Tarakanita Rahmawati, Tarakan \\ ${ }^{2}$ Program Studi Akuntansi, STIE YKPN, Yogyakarta \\ ${ }^{3)}$ Program Studi Teknik Informatika, FTI Universitas Islam Indonesia, Yogyakarta \\ ${ }^{1)}$ Jalan Yos Sudarso No. 8, Tarakan, Kalimantan Utara \\ Email: fadlan@ppkia.ac.id
}

\begin{abstract}
The large number of institutions that use information technology (IT) to help run their usiness processes cannot be separated from various risks to IT. The internal control system is one way that can be used to deal with and even minimize the impact of various risks and COSO Internal Control is one of the frameworks that can be used. The "XYZ" College is one of the educational institutions that have used IT, especially to assist every activity related to students. At present, there are no assessments related to the internal control system in the utilization and management of IT contained in the institution, so it is not known whether the control system is running well or not. For this reason, this study was conducted with the aim of assessing whether the internal control system is currently in accordance with the principles of good internal control based on the COSO Internal Control Framework. The results showed that indirectly the "XYZ" College had applied several principles contained in the COSO Internal Control, even being quite good with a value of 3.28 from a scale of 5.0.
\end{abstract}

Keywords : COSO, Assessment, Internal Control System, Information Technology

Abstrak

Banyaknya institusi yang memanfaatkan teknologi informasi (TI) untuk membantu menjalankan proses bisnis mereka tidak dapat terlepas dari berbagai macam risiko terhadap TI. Sistem pengendalian internal merupakan salah satu cara yang dapat digunakan untuk menghadapi bahkan meminimalisir dampak dari berbagai risiko tersebut dan COSO Internal Control merupakan salah satu framework yang dapat digunakan. Perguruan Tinggi "XYZ" merupakan salah satu institusi pendidikan yang telah menggunakan TI, khususnya untuk membantu setiap aktivitas yang berhubungan dengan mahasiswa. Saat ini, belum ada penilaian terkait dengan sistem pengendalian internal pada pemanfaatan maupun pengelolaan TI yang terdapat pada institusi tersebut, sehingga tidak diketahui apakah sistem pengendalian tersebut telah berjalan dengan baik atau tidak. Untuk itu, penelitian ini dilakukan dengan tujuan untuk menilai apakah sistem pengendalian internal saat ini telah sesuai dengan prinsipprinsip pengendalian internal yang baik berdasarkan COSO Internal Control Framework. Hasil penelitian menunjukkan bahwa secara tidak langsung Perguruan Tinggi "XYZ" telah menerapkan beberapa prinsip yang terdapat pada COSO Internal Control, bahkan berada tergolong cukup baik dengan nilai sebesar 3.28 dari skala 5.0.

Kata kunci : COSO, Penilaian, Sistem Pengendalian Internal, Teknologi Informasi 


\section{Pendahuluan}

Pentingnya informasi bagi sebuah institusi membuat pemanfaatan teknologi informasi (TI) semakin banyak dilakukan diberbagai institusi [1]. Informasi sebagai salah satu aset utama dalam sebuah institusi membuat berbagai institusi memanfaatkan teknologi informasi untuk mengelola dan menyampaikan informasi dalam mendukung proses bisnis yang mereka lakukan [2], [3]. Selain itu, penelitian yang dilakukan oleh [4] menunjukkan bahwa memaksimalkan investasi dan pemanfaatan TI pada perusahaan dapat mengarahkan perusahaan untuk meraih profitabilitas dan efektivitas yang lebih tinggi. Berbagai jenis risiko dapat terjadi pada pemanfaatan maupun pengelolaan TI. Risiko terhadap TI pada institusi dapat berakibat fatal dan membahayakan kerahasiaan (confidentiality), integritas (integrity) dan ketersediaan (availability) informasi dalam suatu institusi [2], sehingga dapat mempengaruhi kinerja dari TI dalam suatu institusi, yang pada akhirnya dapat menghambat institusi dalam mencapai suatu tujuan.

Sistem Pengendalian Internal (SPI) merupakan salah satu alternatif yang dapat digunakan sebagai pedoman bagi perusahaan untuk membantu manajer dalam mencapai tujuan yang telah ditetapkan [1], [5], [7]. Beberapa penelitian lain terkait dengan pemanfaatan SPI, diantaranya penelitian yang dilakukan oleh [8] terkait dengan SPI pada industri rumah makan atau restaurant dan [9] pada industri perbankan dan telekomunikasi. Terdapat beberapa framework yang bisa digunakan terkait dengan sistem pengendalian internal seperti COSO IC, SAC Control and Audit System, COBIT, SAS 55 \& SAS 78, dan Article 404 of The Sarbanes - Oxley Act [10]. Penelitian yang dilakukan oleh Mukhina (2015) [10] menyatakan bahwa SPI oleh COSO memiliki cakupan yang lebih luas dibandingkan dengan beberapa framework lainnya.

Penilaian terhadap keberadaan dan efektifitas sistem pengendalian internal penting untuk dilakukan [1]. Menurut [11], penilaian penting dilakukan untuk mengetahui sejauh mana posisi dan peran pengendalian internal pada institusi, mengingat pentingnya sistem pengendalian internal dalam suatu institusi. COSO ICF dapat digunakan untuk melakukan penilaian terhadap pengendalian internal yang ada pada suatu institusi [1]. Penelitian yang dilakukan oleh Pakadang (2013), menggunakan COSO ICF sebagai kerangka untuk melakukan evaluasi pengendalian internal di sektor rumah sakit. Penelitian ini bersifat deskriptif kualitatif dan menggunakan alat ukur berupa dua pilihan yaitu sesuai atau tidak sesuai dengan indikator yang telah ditetapkan. Penelitian lainnya dilakukan oleh [13] yang menggunakan COSO ICF untuk melakukan penilaian pada sistem pengendalian internal pada sektor perbankan. Namun, penelitian ini hanya menggunakan 2 komponen dari COSO ICF dalam melakukan evaluasi yaitu komponen control environment dan monitoring activities.

Perguruan Tinggi "XYZ" merupakan salah satu perguruan tinggi di pulau Kalimantan. Saat ini, sistem pengendalian internal pada pengelolaan TI yang ada pada Perguruan Tinggi "XYZ" didasarkan pada pengalaman pihak manajemen dalam menghadapi berbagai risiko, serta tidak didasarkan pada best practice atau framework yang telah ada. Hingga kini belum ada pengkajian terhadap sistem pengendalian internal tersebut, apakah pengendalian internal tersebut telah efektif atau tidak, dan mengingat pentingnya melakukan penilaian SPI untuk mengetahui posisi dari SPI dalam sebuah institusi, maka pada penelitian ini akan dilakukan penilaian terhadap sistem pengendalian internal pada Perguruan Tinggi "XYZ", khususnya terkait pada sektor pengelolaan dan pemanfaatan TI dengan didasarkan pada framework COSO Internal Control. Pertanyaan penelitian pada penelitian ini adalah bagaimana menilai kesesuaian antara SPI pada Perguruan Tinggi "XYZ" dengan framework COSO Internal Control?, dan Apakah SPI pada Perguruan Tinggi "XYZ" telah sesuai dengan prinsip-prinsip pada COSO Internal Control? 


\section{Metodologi Penelitian}

\subsection{COSO Internal Control}

COSO Internal Control merupakan salah satu framework terkait dengan sistem pengendalian internal. COSO Internal Control Framework adalah framework yang pertama kali dirilis pada tahun 1992 oleh Committee of Sponsoring Organizations of the Treadway Commission (COSO). Pada tahun 1985, National Commission on Fraudulent Financial Reporting (The Treadway Commission) menugaskan The Committee of Sponsoring Organizations (COSO) untuk mengidentifikasi faktor-faktor yang menyebabkan adanya kecurangan atau fraud pada laporan keuangan diberbagai perusahaan dan membuat rekomendasi untuk mengatasi hal tersebut, sejak saat itulah framework COSO Internal Control mulai dikembangkan untuk menjadi pedoman dalam manajemen risiko dan sistem pengendalian internal perusahaan [5]. COSO Internal Control dirancang untuk membantu institusi dalam menetapkan, menilai, dan meningkatkan kontrol internal yang dimiliki [14]. Adapun model dari COSO Internal Control Framework dapat dilihat pada Gambar 1.

Pada Gambar 1, terlihat bahwa framework ini terdiri atas lima komponen utama yaitu Control Environment, Risk Assessment, Control Activity, Information and Communication, dan Monitoring Activities [15]. Kelima komponen utama tersebut merupakan bagian dari kerangka kerja yang bersifat holistik yang diperlukan untuk memperkuat efisiensi dalam manajemen institusi [8]. Dalam sistem pengendalian internal yang efektif, lima komponen dari COSO Internal Control harus dapat diimplementasikan untuk mencapai tujuan institusi. Berdasarkan rilis terbaru dari COSO ICF pada tahun 2013, kelima komponen tersebut kemudian diturunkan lagi menjadi 17 prinsip [14].

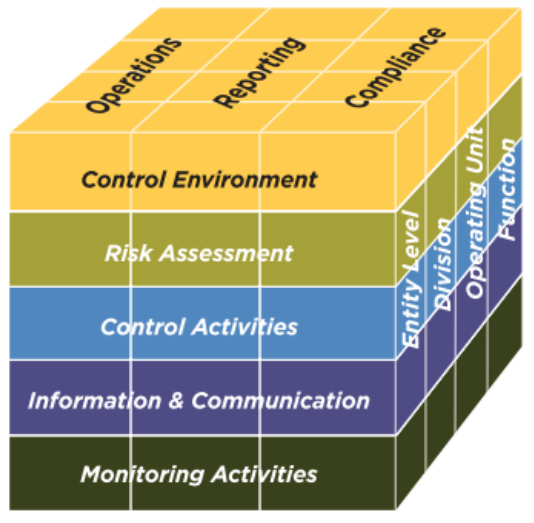

\section{Gambar 1. COSO Internal Control Framework Cube[6]}

Dari ketujuh belas prinsip tersebut, prinsip 1 hingga 5 termasuk kedalam komponen Control Environment, prinsip 6 hingga 9 termasuk kedalam komponen Risk Assessment, prinsip 10 hingga 12 termasuk kedalam komponen Control Activity, prinsip 13 hingga 15 termasuk kedalam komponen Information and Communication, yang terakhir prinsip 16 dan 17 masuk kedalam komponen Monitoring Activities.

\subsection{Tahapan Penelitian}

Pada penelitian ini terdapat beberapa tahapan yang akan dilalui. Tahapan penelitian ini dibuat dengan tujuan untuk mempermudah penulisan laporan penelitian, sehingga menjadi lebih sistematis dan terarah. Secara garis besar, tahapan penelitian tersebut dapat dilihat pada Gambar 2. Pada Gambar 2 tersebut, akan menunjukan tahapan penelitian yang dimulai dari studi pustaka hingga tahapan hasil terkait dengan penelitian yang dilakukan. 


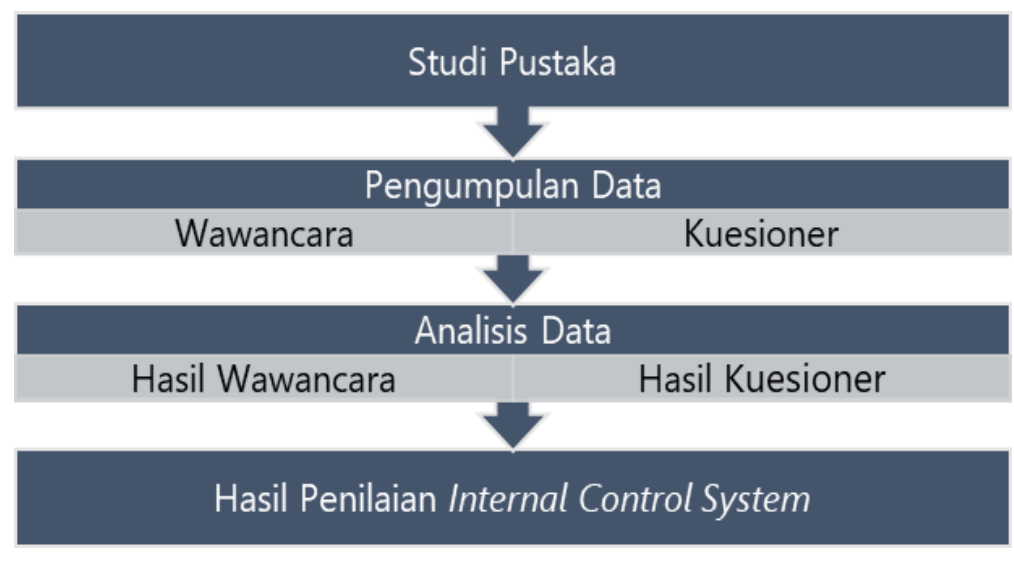

Gambar 2. Tahapan Penelitian

Pada Gambar 2, terlihat bahwa tahapan pertama diawali dengan melakukan studi pustaka, tujuan dilakukannya studi pustaka dalam penelitian ini adalah untuk mengetahui informasi penelitian-penelitian terdahulu yang terkait dengan topik penelitian yang sedang diteliti, yaitu terkait dengan sistem pengendalian internal dan COSO Internal Control. Tahapan kedua merupakan pengumpulan data. Pada penelitian ini pengempulan data dilakukan dengan wawancara dan kuesioner. Wawancara dilakukan untuk mendapatkan informasi mengenai pemanfaatan maupun pengelolaan teknologi informasi dan juga mengenai sistem pengendalian internal yang ada saat ini dari sudut pandang pimpinan institusi. Selain wawancara, penelitian ini juga menggunakan kuesioner dalam mengumpulkan data. Daftar pertanyaan yang digunakan dalam kuesioner ini didasarkan pada prinsip-prinsip dari COSO Internal Control. Pada kuesioner ini para responden akan diminta untuk memberikan pendapatnya terhadap dua hal penting. Yang pertama adalah apakah pernyataan yang diajukan di dalam kuesioner telah diterapkan atau terdapat pada institusi responden. Yang kedua, responden diminta untuk memberikan penilaian terhadap jalannya pernyataan atau penerapan dari prinsip-prinsip COSO Internal Control di Institusi.

Analisis data akan dilakukan terhadap data hasil wawancara maupun kuesioner. Tahapan analisis data wawancara bertujuan untuk menganalisis data wawancara yang telah dikumpulkan. Setelah data dikumpulkan melalui kuesioner, selanjutnya dilakukan pengolahan data kuesioner tersebut. Pengolahan data ini menggunakan persamaan dengan mengacu pada penelitian yang dilakukan oleh [16]. Persamaan tersebut dapat dilihat pada persamaan 3.1.

$$
\text { tingkat kematangan atribut }=\frac{2 \text { total jawaban } * b o b o t}{\text { jumlah responden }}
$$

Pada penelitian ini, perhitungan tingkat kematangan yang terdapat pada persamaan 1 akan digunakan sebagai acuan dalam menghitung penilaian terhadap tiap-tiap pernyataan mengenai penerapan atau implementasi komponen COSO Internal Control di lokasi penelitian. Dimana hasil penilaian tersebut didapat dari total jawaban responden di kali dengan bobot kemudian dibagi dengan banyaknya jumlah responden. Persamaan 1 tersebut akan digunakan untuk menghitung jawaban responden terhadap masing-masing pernyataan yang terdapat dalam kuesioner. Hasil perhitungan dengan Persamaan 1 tersebut akan menunjukkan nilai untuk tiap-tiap pernyataan atau atribut yang mewakili masing-masing prinsip dari COSO Internal Control. Setelah didapatkan hasil terhadap masing-masing pernyataan, dilakukan perhitungan nilai untuk tiap-tiap prinsip dari COSO Internal Control. Perhitungan dilakukan dengan menghitung nilai rata-rata dari semua pernyataan yang mewakili tiap-tiap prinsip. Proses perhitungan rata-rata seperti ini kemudian juga dilakukan 
untuk mendapatkan nilai dari tiap-tiap komponen, hingga nilai sistem pengendalian internal secara keseluruhan.

\section{Hasil dan Pembahasan}

\subsection{Profil Responden}

Pada penelitian ini dilakukan pengumpulan data dengan menggunakan wawancara maupun kuesioner. Pengumpulan data dilakukan terhadap beberapa responden yang ada dilokasi penelitian. Adapun profil responden yang digunakan pada penelitian ini dapat dilihat pada Tabel 2.

Tabel 2. Profil Responden

\begin{tabular}{|l|l|c|c|}
\hline ID & \multicolumn{1}{|c|}{ Jabatan } & Lama Kerja (Tahun) & Pendidikan Terakhir \\
\hline R1 & Kepala Laboratorium & 7 & S1 \\
\hline R2 & Staf Bagian Server & 3 & S1 \\
\hline R3 & Staf Lab. Instalasi & 5 & S1 \\
\hline R4 & Asisten Laboratorium & 3 & S1 \\
\hline R5 & Asisten Laboratorium & 3 & S1 \\
\hline R6 & Kabag Perlengkapan & 5 & S1 \\
\hline R7 & Ka. Prodi TI & 11 & S2 \\
\hline R8 & Kabag Sinfo & 13 & S2 \\
\hline R9 & Plt. Ketua Sekolah Tinggi & 18 & S2 \\
\hline
\end{tabular}

Pada Tabel 2 terlihat bahwa jumlah responden sebanyak 9 orang. Dengan rentang lama kerja antara 3 hingga 18 tahun. Secara keseluruhan, sembilan responden tersebut merupakan pihak-pihak yang saat ini mengetahui mengenai pemanfaatan maupun pengelolaan teknologi informasi di Perguruan Tinggi "XYZ". Pada penelitian ini, pengumpulan data menggunakan wawancara dilakukan kepada pimpinan perguruan tinggi, yang pada penelitian ini diwakili oleh Plt. Ketua Sekolah Tinggi (ID R9). Sedangkan, untuk pengumpulan data menggunakan kuesioner pada penelitian ini dilakukan terhadap responden mulai dari ID responden R1 hingga R8.

\subsection{Hasil Wawancara}

Wawancara pada penelitian dilakukan terhadap pimpinan perguruan tinggi yang pada penelitian ini diwakili oleh Plt. Ketua Sekolah Tinggi (ID responden R9). Wawancara ini bertujuan ini untuk mendapatkan informasi dari pimpinan sekolah tinggi selaku pemangku kepentingan tertinggi di Institusi mengenai pemanfaatan maupun pengelolaan, serta pengendalian internal yang ada saat ini.

Berdasarkan hasil wawancara yang dilakukan terhadap Plt. Ketua Sekolah Tinggi, ada beberapa informasi penting yang dapat diambil. Yang pertama mengenai pemanfaatan teknologi informasi yang ternyata telah dimulai sejak institusi didirikan atau tepatnya sejak tahun 2000. Adapun tujuan utama dari pemanfaatan teknologi informasi tersebut adalah untuk membantu berbagai proses kerja di dalam institusi. Sebagai institusi perguruan tinggi, tentu banyak hal yang dapat diselesaikan dengan bantuan teknologi informasi. Salah satunya adalah untuk membantu setiap proses yang langsung berhubungan dengan mahasiswa agar dapat berjalan secara maksimal. Termasuk diantaranya adalah proses yang terkait dengan keuangan maupun perkuliahan. Hingga saat ini, menurut Plt. Ketua Sekolah Tinggi pemanfaatan teknologi informasi tersebut dianggap telah mampu mencapai tujuan yang telah ditetapkan. Terkait dengan sistem pengendalian internal, Responden nomor 9 (R9) yang juga merupakan Plt. Ketua Sekolah Tinggi mengatakan bahwa: "Untuk sistem pengendalian atau kontrol terhadap pengelolaan teknologi informasi saat ini telah dilakukan dan telah berjalan cukup baik selama ini. Namun, kami tidak akan berhenti sampai disini, kami akan tetap 
melakukan inovasi dalam hal sistem kontrol atau pengendalian, sehingga kontrol dapat dilakukan secara maksimal di semua bagian”.

Pernyataan tersebut menunjukkan dua hal penting, yang pertama bahwa saat ini pengendalian internal telah dijalankan dengan cukup baik. Namun saat ini, sistem pengendalian internal yang ada hanya didasarkan pada pengalaman pihak manajemen dalam menghadapi berbagai risiko, serta tidak didasarkan pada best practice atau framework tertentu. Walaupun demikian, berdasarkan pernyataan responden sebelumnya juga menunjukkan bahwa pimpinan memiliki komitmen terhadap sistem pengendalian internal yang ada di institusi. Komitmen ini sangat penting dan secara tidak langsung selaras dengan prinsip-prinsip dari COSO Internal Control, khususnya prinsip yang terdapat pada komponen Control Environment. Hal ini kemudian juga didukung oleh pernyataan responden tersebut terkait dengan kegiatan monitoring berikut ini: "Kegiatan monitoring telah berjalan sebagaimana tugas pokok di masing-masing bagian. Tetapi sekali lagi, ingin saya sampaikan bahwa kami tidak berhenti disini, inovasi-inovasi akan terus kami lakukan salah satunya dengan menggunakan berbagai media TI sebagai bentuk kontrol atau untuk monitoring terhadap kegiatan kontrol terhadap pemanfaatan TI di institusi kami”. Hal tersebut juga menunjukkan bahwa saat ini pimpinan memiliki komitmen tidak hanya pada Control Environment, tetapi juga pada tahapan monitoring, yang juga merupakan salah satu komponen dari COSO Internal Control.

\subsection{Hasil Penilaian Internal Control System}

Penilaian Sistem Pengendalian Internal dilakukan dengan menyebarkan kuesioner kepada responden. Terdapat 51 jumlah pernyataan yang terdapat pada kuesioner tersebut dengan delapan orang yang menjadi responden. Hasil kuesioner yang telah dijawab oleh responden kemudian direkap untuk mengetahui seberapa banyak responden yang memilih jawaban yang sama untuk tiap-tiap pernyataan. Selanjutnya, hasil rekapitulasi tersebut dihitung dengan menggunakan Persamaan 1 yang terdapat pada Bagian 2. Secara keseluruhan hasil perhitungan tersebut dapat dilihat pada Gambar 3.

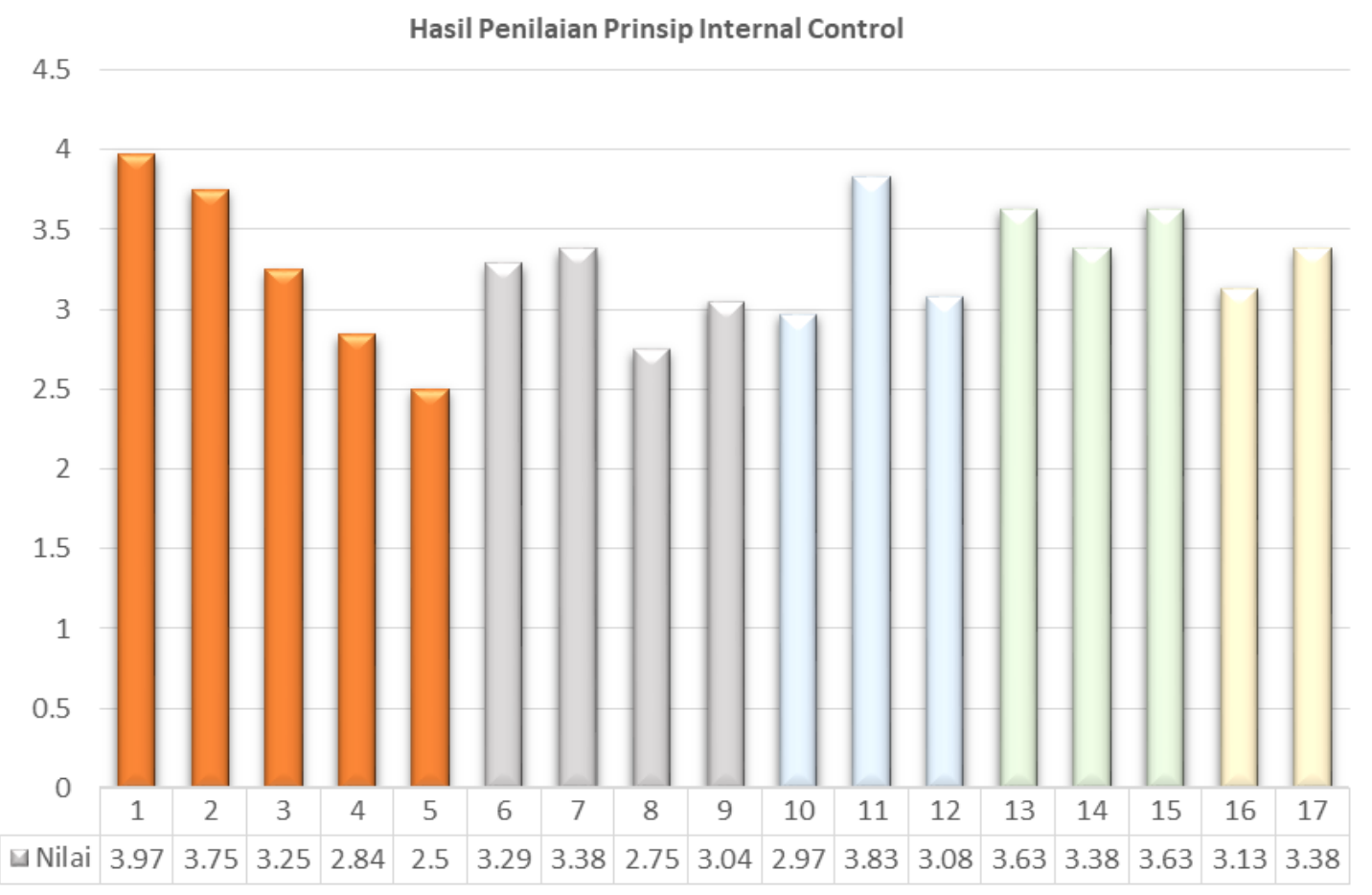

Gambar 3. Grafik Hasil Penilaian Prinsip Pengendalian Internal COSO Internal Control 
Pada Gambar 3 dapat terlihat bahwa dari ketujuh belas prinsip COSO Internal Control, tiga belas diantaranya telah memiliki nilai yang cukup yaitu berada diatas 3.0. Sedangkan, empat prinsip lainnya memiliki nilai yang tergolong kurang yaitu berada dibawah 3.0. Kelima prinsip tersebut adalah prinsip nomor 4, 5, 8 dan 10. Prinsip 4 dan prinsip 5 termasuk dalam komponen Control Environment, prinsip 8 termasuk dalam komponen Risk Assessment, dan prinsip 10 termasuk dalam komponen Control Objectives. Kelima prinsip inilah yang nantinya dapat menjadi prioritas dalam pemberian rekomendasi untuk peningkatan, sehingga dapat menjadi lebih baik.

Jika dilihat pada Gambar 3, prinsip pertama memiliki nilai tertinggi sebesar 3.97. Prinsip pertama tersebut termasuk dalam komponen Control Environment, tepatnya terkait dengan komitmen dari pimpinan terhadap integritas dan nilai-nilai etika yang baik pada sistem pengendalian internal. Nilai 3.97 ini juga mengkonfirmasi hasil wawancara yang telah dilakukan pada pimpinan sekolah tinggi (ID responden R9). Dimana pada hasil wawancara tersebut, pimpinan terlihat memiliki komitmen yang cukup tinggi terhadap sistem pengendalian internal di institusi tersebut.

Setelah nilai untuk masing-masing prinsip didapatkan, dilakukan perhitungan untuk mendapatkan nilai dari kelima komponen COSO Internal Control. Proses perhitungan untuk kelima komponen tersebut didapat dengan menghitung rata-rata dari nilai prinsip yang terdapat pada tiap-tiap komponen. Proses terakhir dilakukan untuk mendapatkan nilai sistem pengendalian internal secara keseluruhan di Perguruan Tinggi "XYZ". Nilai ini didapat dengan menghitung rata-rata dari nilai kelima komponen COSO Internal Control. Hasil perhitungan tersebut dapat dilihat pada Gambar 4.

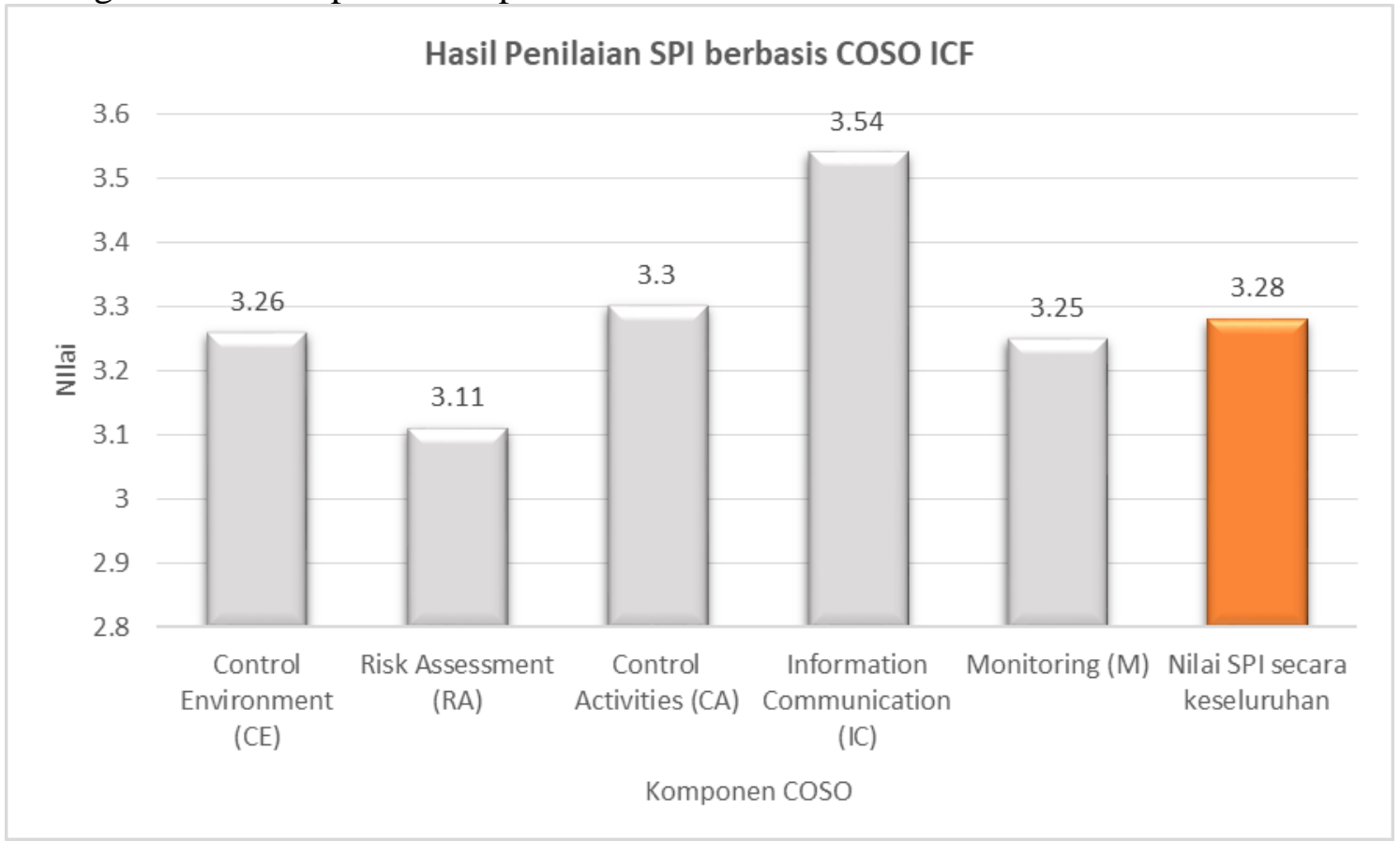

Gambar 4. Grafik Hasil Penilaian SPI berbasis COSO Internal Control

Berdasarkan Gambar 4, terlihat bahwa nilai dari komponen Information and Communication memiliki nilai tertinggi dibandingkan dengan komponen lainnya, yaitu sebesar 3.54. Ini menunjukkan bahwa Perguruan Tinggi "XYZ" telah melakukan komunikasi terkait dengan kebijakan-kebijakan dalam pemanfaatan maupun pengelolaan TI yang harus diikuti oleh tiap-tiap individu yang ada di dalam institusi dengan cukup baik. Selain itu, nilai ini juga menunjukkan bahwa selama ini institusi telah mampu menggunakan berbagai informasi yang relevan dan berkualitas dalam mendukung setiap proses bisnis yang terdapat di dalam institusi. Hal ini tentu sangat baik, karena dengan digunakannya informasi yang 
relevan dan berkualitas maka setiap proses bisnis yang dijalankan dapat memberikan hasil yang maksimal. Tentu hal ini tidak dapat terlepas dari peran Bagian Sistem Informasi di Perguruan Tinggi "XYZ" yang memiliki tugas dan tanggung jawab dalam mengelola berbagai jenis informasi di Perguruan Tinggi "XYZ".

Pada Gambar 4, terlihat bahwa Control Activities memiliki nilai tertinggi kedua, yaitu sebesar 3.26. Ini menunjukkan bahwa aktivitas pengendalian yang ada saat ini untuk melakukan mitigasi risiko, terutama risiko yang dianggap terlalu berisiko bagi institusi selama penilaian risiko telah berjalan dengan cukup baik. Selanjutnya, terkait dengan aktivitas untuk melakukan monitoring terhadap setiap proses atau pengendalian internal yang ada dalam Perguruan Tinggi "XYZ" juga telah berjalan dengan cukup baik dan sesuai dengan prinsip 16 dan 17 COSO Internal Control. Hal ini ditandai dengan nilai dari komponen monitoring sebesar 3.25.

Control Environment memiliki nilai sebesar 3.24 dan terpaut 0.01 dari komponen monitoring. Nilai ini menunjukkan bahwa saat ini lingkungan pengendalian yang ada saat ini sudah cukup baik. Khususnya pada komitmen pimpinan institusi terhadap pengendalian internal dan perilaku yang beretika di dalam bekerja, khususnya dalam pengelolaan dan pemanfaatan TI di Perguruan Tinggi "XYZ". Namun, pada komponen ini terdapat dua prinsip yang masih memiliki nilai rendah, yakni prinsip 4 dan prinsip 5. Untuk itu, kedepannya masih diperlukan perbaikan terhadap penerapan prinsip-prinsip tersebut di Perguruan Tinggi "XYZ". Komponen dengan nilai terendah adalah komponen Risk Assessment dengan nilai sebesar 3.08. Hal ini dapat terjadi karena masih banyak yang perlu diperbaiki dalam hal penilaian terhadap berbagai risiko yang mungkin dapat terjadi selama pemanfaatan maupun pengelolaan TI di Perguruan Tinggi "XYZ". Khususnya terkait dengan penilaian risiko fraud (prinsip 8) dengan nilai sebesar 2.75 dan identifikasi perubahan signifikan (prinsip 9) yang salah satu atributnya memiliki nilai rendah berdasarkan hasil perhitungan yang terdapat pada Gambar 3.

Dengan nilai sistem pengendalian internal secara keseluruhan sebesar 3.28, dapat ditarik kesimpulan bahwa penerapan sistem pengendalian internal pada Perguruan Tinggi "XYZ" secara tidak langsung telah menerapkan komponen dan prinsip-prinsip dari COSO Internal Control dengan cukup baik. Hal ini juga sejalan dengan apa yang dikatakan oleh pimpinan institusi pada hasil wawancara dibagian sebelumnya bahwa pengendalian internal untuk pengelolaan maupun pemanfaatan teknologi informasi di Perguruan Tinggi "XYZ" hingga saat ini telah berjalan dengan cukup baik. Pada Gambar 4, dapat dilihat bahwa kelima komponen utama dari COSO Internal Control mulai dari Control Environment, Risk Assessment, Control Activities, Information and Communication, dan Monitoring memiliki nilai yang cenderung hampir sama atau tidak memiliki jarak yang terlalu jauh antara satu komponen dengan komponen lainnya, yaitu berada pada kisaran nilai 3 dari 5. Sehingga, selain menunjukkan secara tidak langsung bahwa Perguruan Tinggi "XYZ" telah menerapkan prinsip-prinsip yang terdapat pada tiap-tiap komponen COSO Internal Control, hal ini juga menunjukkan bahwa terdapat keseimbangan dari penerapan tiap-tiap komponen tersebut.

Meskipun hasil penilaian menunjukan bahwa saat ini penerapan sistem pengendalian internal di Perguruan Tinggi "XYZ" telah cukup baik, tentu saja masih diperlukan adanya perbaikan untuk dapat meningkatkan penerapan dari beberapa prinsip sistem pengendalian internal tersebut. Hal ini juga sejalan dengan apa yang di inginkan dan dikatakan oleh pimpinan institusi seperti berikut ini: "Kami tidak akan berhenti sampai disini, kami akan tetap melakukan inovasi dalam hal sistem kontrol atau pengendalian, sehingga kontrol dapat dilakukan secara maksimal". Untuk itu diperlukan suatu rekomendasi perbaikan, khususnya pada prinsip-prinsip tertentu dari tiap-tiap komponen yang memiliki nilai yang kurang agar kedepannya terjadi peningkatan dalam penerapan sistem pengendalian internal di Perguruan Tinggi "XYZ", khususnya pada pemanfaatan maupun pengelolaan teknologi informasi. 


\section{Kesimpulan}

Berdasarkan hasil penelitian yang telah dilakukan terkait dengan sistem pengendalian internal pada pemanfaatan maupun pengelolaan TI di Perguruan Tinggi "XYZ", maka terdapat beberapa hal yang dapat disimpulkan:

1. Secara tidak langsung Perguruan Tinggi "XYZ" telah menerapkan beberapa prinsip yang terdapat pada COSO Internal Control dengan cukup baik. Namun dari ke tujuh belas prinsip COSO Internal Control, terdapat empat prinsip yang implementasinya masih tergolong kurang, karena memiliki nilai dibawah 3.0 dari skala 5.0. Keempat prinsip tersebut adalah prinsip 4 dan 5 (Control Environment), prinsip 8 (Risk Assessment), serta prinsip 10 (Control Activities)

2. Secara keseluruhan nilai dari sistem pengendalian internal pada pemanfaatan dan pengelolaan TI di Perguruan Tinggi "XYZ" sebesar 3.28 dari skala 5.0. Dimana kelima komponen utama dari COSO Internal Control memiliki nilai yang cenderung hampir sama atau tidak memiliki jarak yang terlalu jauh antara satu komponen dengan komponen lainnya. Hal ini menunjukkan bahwa terdapat keseimbangan dari penerapan tiap-tiap komponen tersebut.

Selain dua poin kesimpulan tersebut, terdapat beberapa saran yang dapat di tindak lanjuti untuk penelitian di masa yang akan datang:

1. Penelitian di masa yang akan datang dapat dilakukan dengan tidak hanya menilai kondisi sistem pengendalian saat ini, namun juga menilai kondisi sistem pengendalian yang diharapkan

2. Penelitian di masa yang akan datang dapat dilakukan dengan tidak hanya berhenti hingga hasil penilaian, juga dapat memberikan rekomendasi perbaikan terhadap beberapa hasil penilaian yang dianggap kurang.

\section{Ucapan Terimakasih dan Catatan}

Terima kasih pada pihak-pihak yang telah berkenan untuk membantu menjadi responden dalam penelitian ini. Penelitian ini merupakan bagian atau ringkasan dari penelitian tesis dengan judul "Sistem Pengendalian Internal Pada Perguruan Tinggi Berbasis COSO ICF".

\section{Daftar Pustaka}

[1] M. Fadlan, "Pendekatan Dalam Menilai Internal Control System Pada Pemanfaatan Teknologi Informasi : Sebuah Kajian Pustaka," J. INSTEK (Informatika Sains dan Teknol., vol. 3, no. 2, pp. 181-190, 2018.

[2] I. Lopes and P. Oliveira, "New Perspectives in Information Systems and Technologies, Volume 1," vol. 275, 2014.

[3] K. Hedström, E. Kolkowska, F. Karlsson, and J. P. Allen, "Value conflicts for information security management," J. Strateg. Inf. Syst., vol. 20, no. 4, pp. 373-384, 2011.

[4] C. Marinagi, P. Trivellas, and D. P. Sakas, "The Impact of Information Technology on the Development of Supply Chain Competitive Advantage," Procedia - Soc. Behav. Sci., 2014.

[5] A. Amudo and E. L. Inanga, "Evaluation of Internal Control Systems: A Case Study from Uganda," Int. Res. J. Financ. Econ., vol. 27, no. 27, pp. 124-144, 2009.

[6] R. H. Chenhall, "Management control systems design within its organizational context: findings from contingency-based research and directions for the future," vol. 28, pp. 127-168, 2003.

[7] L. F. Spira and M. Page, "Risk management: The reinvention of internal control and the changing role of internal audit," Accounting, Audit. Account. J., vol. 16, no. 4, pp. 640-661, 2003. 
[8] L. Frazer, "The Effect Of Internal Control On The Operating Activities Of Small Restaurants," J. Bus. Econ., vol. 10, no. 6, pp. 361-374, 2012.

[9] B. Mahadeen, R. H. Al-Dmour, B. Y. Obeidat, and A. Tarhini, "Examining the Effect of the Organization's Internal Control System on Organizational Effectiveness: A Jordanian Empirical Study," Int. J. Bus. Adm., vol. 7, no. 6, pp. 22-41, 2016.

[10] A. S. Mukhina, "International concept of an assessment of internal control efficiency in the conduct of an audit," Asian Soc. Sci., 2015.

[11] M. Badara and S. Saidin, "Impact of the effective internal control system on the internal audit effectiveness at local government level," J. Soc. Dev. Sci., vol. 4, no. 1, pp. 16-23, 2013.

[12] D. Pakadang, "Evaluasi Penerapan Sistem Pengendalian Intern Penerimaan Kas Pada Rumah Sakit Gunung Maria Di Tomohon,” J. EMBA, vol. 1, no. 4, pp. 213-223, 2013.

[13] P. Ayagre, I. Appiah-Gyamerah, and J. Nartey, "The Effectiveness of Internal Control Systems of Banks. The Case of Ghanaian Banks," Int. J. Account. Financ. Report., vol. 4, no. 2, p. 377, 2014.

[14] COSO, "Internal Control - Integrated Framework," Comm. Spons. Organ. Treadw. Comm., no. May, p. 10, 2013.

[15] COSO, "Internal Control - Integrated Framework," 1992.

[16] L. A. Purwanto and R. T. Dirgahayu, "Pengukuran Tingkat Kematangan Tata Kelola Pengelolaan Permasalahan Sistem Informasi Akademik Menggunakan Framework ( Maturity Level Measurement of Governance of Academic Information System Problems Management Using COBIT 4 . 1 Framework )," JUITA, vol. V, no. November, pp. 103-113, 2017. 